\title{
PERAN SEKTOR PERKEBUNAN DALAM PEREKONOMIAN SUMATERA UTARA
}

\author{
Ina Namora Putri Siregar \\ Universitas Prima Indonesia \\ Kampus 2, Jalan Sekip, Simpang Sikambing, telp. (061) 4578870 \\ Email: siregar ina@ymail.com \\ Eko Wahyu Nugrahadi \\ Arwansyah \\ Program Studi Ilmu Ekonomi Program Pasca Sarjana \\ Universitas Negeri Medan \\ Jalan Williem Iskandar, Pasar V Medan Estate, Sumatera Utara 20221 \\ Email: ewahyunugrahadi@yahoo.com \& arwan ibnu@yahoo.com
}

\begin{abstract}
The plantation are one of the sectors that are considered able to survive and make a significant contribution in the post-crisis economic recovery. The purpose of this study was to analyze the relationship plantation sector and the impact of the plantation sector gross output, labor and households in the economy in North Sumatra. In measuring and analyzing the tables used are Social Accounting Matrix (SAM) or a Social Accounting Matrix (SAM) of North Sumatra. In connection table SAM North Sumatra province is not yet available, therefore in this study was built tables SAM 1995 and 2009, the structure refers to the processed products which have been built by Ginting (2006). Based on the analysis it appears that the role of plantations in North Sumatra as indicated by the results obtained have power spread index greater $(>1)$ means the plantation sector has the ability to attract growth in upstream sectors (backward linkages). In addition, this sector has a multiplier of gross output of more than three, which means when in the injection of one unit in this sector, then the resulting output has tripled over the breadth of the effect of forward and backward. And based on the order of rank, occupies five large estates.
\end{abstract}

Keywords: Plantation sector, Effects Forward and backward linkage

QE Journal | Vol.03 - No.03 September 2014 - 179 


\section{PENDAHULUAN}

I ndonesia dikenal sebagai negara agraris oleh karena itu dalam melaksanakan pembangunan ekonomi seyogyanya lebih mengandalkan sektor pertanian. Sektor pertanian meliputi subsektor tanaman bahan makanan, perkebunan, holtikultura, perikanan, peternakan dan kehutanan.

Berdasarkan laporan hasil sensus Pertanian (2013), subsektor Perkebunan memiliki jumlah usaha pertanian terbanyak selama periode tahun 2003 sampai dengan tahun 2013. Berdasarkan skala usaha rumah tangga pertanian, Perkebunan memiliki jumlah usaha sebesar 858.655 pada tahun 2003, dan meningkat jumlahnya menjadi 938.842 pada tahun 2013 (terjadi kenaikan 9,34\%), bandingkan dengan Tanaman pangan (yang menempati urutan kedua) hanya sebesar 834.394 (tahun 2003) dan 741.067 (tahun 2013). Demikian pula berdasarkan skala usaha yang berbadan hukum, terdapat jumlah usaha sebanyak 372 (tahun 2003) dan 355 (tahun 2013), bandingkan dengan usaha lainnya (Tanaman Pangan) masing-masing sebanyak 3 dan 4 pada periode tahun yang sama.

Gambaran lebih lanjut tentang kedudukan Perkebunan dengan masingmasing subsektor lainnya dari sektor Pertanian ditunjukkan pada Gambar 1. Dalam hal ini jumlah usaha merupakan penjumlahan bukan saja berdasarkan skala rumahtangga dan yang berbadan hukum, juga mencakup dari skala usaha pertanian lainnya.

Sebagai salah satu subsektor Pertanian, Perkebunan memiliki berbagai komoditi yang difokuskan untuk perdagangan global yaitu seperti: Kopi, Kelapa Sawit, Kakao dan Karet. Luas area Perkebunan yang dikelola secara total untuk jenis tanaman tersebut mencapai 1.594.601 ha. Dari luasan tersebut Sawit memiliki areal yang luas mencapai sebesar 57\%. Akan tetapi tingkat produktivitasnya sebesar 1.5 ton/ha, masih lebih rendah dari Kakao sebesar 18 ton/ha. Sementara itu untuk kedua komoditas lainnya masih memiliki tingkat produktivitas di bawah 1 ton/ha (Karet dan Kopi masingmasing sebesar 0.77 dan 0.71 ton/ha). 


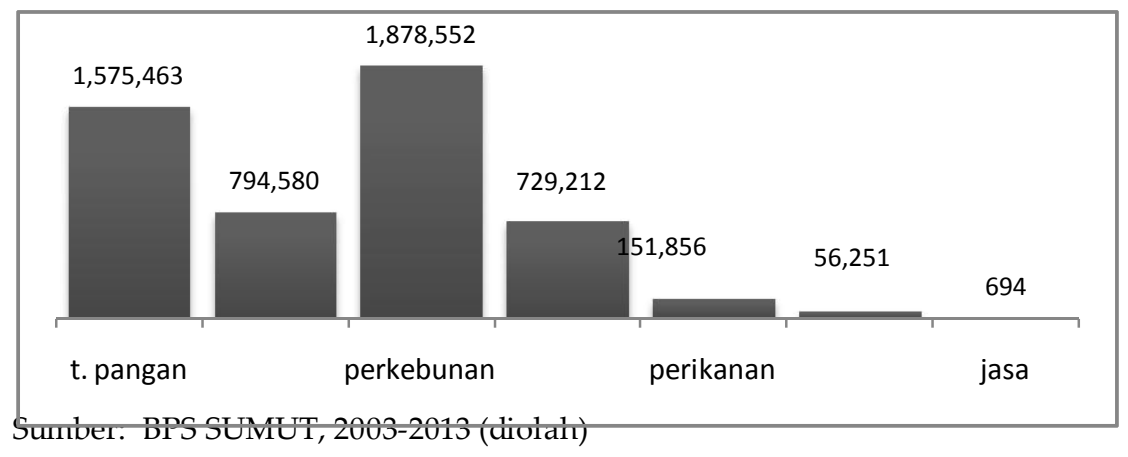

Gambar 1. Perkembangan Jumlah Usaha Pertanian di Sumatera Utara Selama Periode Tahun 2003-2013

Berdasarkan gambaran tersebut, terdapat kondisi inefisien dalam mencapai optimisasi produktivitas. Padahal potensi di pasar dunia, Perkebunan memiliki peluang dan prospek yang dapat meningkatkan perekonomian, khususnya Sumatera Utara. Sehubungan dengan itu dalam studi ini dianalis bagaimana sesungguhnya peran dari sector Perkebunan dalam perekonomian Sumatera Utara.

\section{METODE PENELITIAN}

Data yang digunakan untuk penelitian ini adalah data sekunder yang sebagian besar bersumber dari Badan Pusat Statistik (BPS) provinsi Sumatera Utara. Adapun secara spesifik data yang digunakan tersebut adalah tabel Social Accounting Matrix (SAM) atau Sistem Neraca Sosial Ekonomi (SNSE) Sumatera Utara. Sehubungan tabel SAM Propinsi Sumatera Utara belum tersedia, oleh karena itu dalam studi ini dibangun tabel SAM Tahun 1995 dan 2009 yang strukturnya mengacu pada hasil olahan yang telah dibangun oleh Ginting (2006).

Tabel SAM propinsi Sumatera Utara pada dasarnya merupakan sebuah matriks yang merangkum neraca sosial dan ekonomi di Sumatera Utara secara agregat. Neraca SAM provinsi Sumatera Utara dikategorikan menjadi dua kelompok neraca besar, yakni neraca endogen dan neraca eksogen. Untuk neraca endogen dikelompokkan menjadi tiga blok neraca, yaitu blok neraca faktor produksi, blok neraca institusi dan blok neraca aktivitas produksi. Sedangkan neraca eksogen dapat dipisahkan menjadi neraca kapital, neraca pajak tak langsung dan neraca luar negeri (luar

QE Journal |Vol.03 - No.03 September 2014 - 181 
provinsi Sumatera Utara dan luar negeri). Tabel 1 (Lampiran) menunjukkan klasifikasi neraca SAM provinsi Sumatera Utara yang disusun lebih rinci sebagaimana diperlukan dalam studi ini.

Untuk memperoleh jawaban tujuan penelitian dilakukan analisis berdasarkan pendekatan model SAM. Untuk keperluan ini dilakukan analisis: (1) keterkaitan dan (2) pengganda (multiplier). Kedua analisis yang digunakan dalam studi ini merujuk dari konsep yang telah dikemukakan Isard et.al. (1998). Selanjutnya dilakukan rangking terhadap urutan sektor yang menempati posisi teratas sampai terbawah dari koefisien pengganda (output bruto, tenaga kerja dan pendapatan rumahtangga) dan keterkaitan (langsung dan tidak langsung) ke depan dan ke belakang dan memberikan bobot dimana sektor yang menempati peringkat pertama diberikan skor tertinggi, dan seterusnya sampai pada peringkat paling rendah diberikan skor 1 . Kemudian skor untuk masingmasing sektor dijumlah berdasarkan kategorinya (pengganda dan keterkaitan) kemudian diurutkan, dimana sektor yang memiliki skor total tertinggi ditetapkan sebagai rangking pertama, berikutnya ditetapkan rangking kedua, dan seterusnya sampai pada skor yang terendah ditetapkan rangking paling bawah. Berdasarkan rangking total tersebut selanjutnya teridentifikasi sektor-sektor potensial di Provinsi Sumatera Utara.

Analisis keterkaitan digunakan untuk mengetahui besarnya tingkat keterkaitan suatu sektor terhadap lainnya. Analisis keterkaitan dalam studi ini didasarkan atas kriteria Rasmussen's dual (Daryanto, 1995). Kriteria ini meliputi pengukuran indeks berdasarkan, pertama, kepekaan penyebaran (sensitivity of dispersion) dan daya penyebaran (power dispersion), dan kedua, efek keluasan ke depan (forward spread effect index) dan efek keluasan ke belakang (backward spread effect index).

Kepekaan penyebaran menunjukkan kemampuan suatu sektor untuk mendorong pertumbuhan sektor hilirnya. Indeks kepekaan penyebaran ditentukan sebagai berikut: (Nugrahadi, 2013)

$$
U_{i}=\frac{\frac{1}{n} Z_{i}}{\frac{1}{n^{2}} \sum_{i=1}^{n} Z_{i}}
$$


dimana : $\mathrm{U}_{\mathrm{i}}=$ indeks kepekaan penyebaran; dan $\mathrm{Z}_{\mathrm{i}}=$ nilai

keterkaitan langsung dan tidak langsung ke depan.

Daya penyebaran menunjukkan kemampuan suatu sektor untuk menarik pertumbuhan sektor hulunya. Indeks daya penyebaran ditentukan sebagai berikut:

$$
U_{j}=\frac{\frac{1}{n} Z_{j}}{\frac{1}{n^{2}} \sum_{j=1}^{n} Z_{j}}
$$

dimana: $U_{j}=$ indeks daya penyebaran, dan $Z_{j}=$ nilai keterkaitan langsung dan tidak langsung ke belakang.

Efek keluasan ke depan menunjukkan besarnya keterkaitan ke depan suatu sektor yang disebabkan oleh sejumlah kecil sektor. Indeks efek keluasan ke depan ditentukan sebagai berikut :

$$
S_{i}=\frac{V_{i}}{\sum_{i=1}^{n} \frac{V_{i}}{n}}
$$

dimana: $\mathrm{S}_{\mathrm{i}}=$ indeks efek keluasan ke depan, dan $\mathrm{V}_{\mathrm{i}}=$ koefisien variasi dari keterkaitan ke depan, yang nilainya ditentukan sebagai berikut:

$$
V_{i} \frac{\sqrt{\frac{1}{n-1} \sum_{i=1}^{n}\left(z_{i j}-\frac{1}{\left.n_{i=1}^{n} z_{i j}\right)^{2}}\right.}}{\frac{1}{n_{i=1}^{n} \sum_{i j}}}
$$

Efek keluasan ke belakang menunjukkan besarnya keterkaitan ke belakang suatu sektor yang disebabkan oleh sejumlah kecil sektor. Indeks efek keluasan ke depan ditentukan sebagai berikut:

$$
S_{j}=\frac{V_{j}}{\sum_{i=1}^{n} \frac{V_{j}}{n}}
$$


dimana: $S_{j}=$ indeks efek keluasan ke belakang, dan $V_{j}=$ koefisien variasi dari keterkaitan ke belakang, yang nilainya ditentukan sebagai berikut:

$$
V j=\frac{\sqrt{\frac{1}{n-1} \sum_{j=1}^{n}\left(z_{i j}-\frac{1}{n} \sum_{j=1}^{n} z_{i j}\right)^{2}}}{\frac{1}{n} \sum_{j=1}^{n} z_{i j}}
$$

Analisis pengganda mencoba melihat apa yang terjadi terhadap variabel-variabel endogen tertentu apabila terjadi perubahanperubahan terhadap neraca eksogen. Analisis pengganda yang digunakan dalam penelitian ini adalah pengganda dengan pendekatan rata-rata $\left(\mathrm{Ma}_{\mathrm{a}}\right)$. Analisis pengganda yang menjadi fokus dalam studi ini meliputi jenis pengganda: output bruto (gross output/production multiplier), pengganda tenaga kerja (employment multiplier) dan pengganda pendapatan rumahtangga (household income multiplier).

Pengganda output bruto menunjukkan total dampak terhadap output dalam perekonomian secara keseluruhan akibat adanya peningkatan permintaan output pada suatu neraca i, di mana nilai pengganda ini diperoleh dari penjumlahan koefisien matriks pengganda neraca di blok sektor produksi sepanjang kolom neraca $i$.

$$
X_{j}=\sum_{i=1}^{n} \alpha_{i j}
$$

dimana: $X_{j}=$ pengganda output bruto, dan $\alpha_{i j}=$ koefisien matriks pengganda neraca di blok sektor produksi.

Pengganda tenaga kerja (employment multiplier) menunjukkan total dampak terhadap penyerapan tenaga kerja akibat adanya peningkatan pendapatan pada suatu neraca i. di mana nilai pengganda ini diperoleh dari penjumlahan koefisien matriks pengganda neraca di blok sektor produksi sepanjang kolom neraca i yang terlebih dahulu dikalikan dengan koefisien teknis tenaga kerja. 


$$
E_{j}=\sum_{i=1}^{n} L \cdot \alpha_{i j}
$$

dimana: $\mathrm{E}_{\mathrm{j}}=$ pengganda tenaga kerja, $\alpha_{\mathrm{ij}}=$ koefisien matriks pengganda neraca di blok sektor produksi, dan $\mathrm{L}=$ koefisien matriks tenaga kerja.

Pengganda pendapatan rumahtangga (household income multiplier) menunjukkan total dampak terhadap pendapatan rumahtangga dalam perekonomian akibat adanya peningkatan pendapatan pada suatu neraca i, di mana nilai pengganda ini diperoleh dari penjumlahan koefisien matriks pengganda neraca yang unsurunsurnya termasuk dalam kelompok rumahtangga sepanjang kolom neraca $i$.

$$
H_{j}=\sum_{i=1}^{n} \beta_{i j}
$$

dimana: $H_{j}=$ pengganda pedapatan rumahtangga, dan $\beta_{i j}=$ koefisien matriks pengganda neraca di blok institusi rumahtangga.

\section{HASIL DAN PEMBAHASAN}

\section{Keterkaitan Sektor Perkebunan di Sumatera Utara}

Selama 20 tahun terakhir ini perekonomian di Sumatera Utara tumbuh dan berkembang. Salah satu perkembangan dapat dilihat dari keterkaitan antar sektor. Dalam studi ini dilakukan analisis dampak penyebaran, yang ditunjukkan oleh indeks kepekaan penyebaran dan daya penyebaran, dan efek keluasan (ke depan dan ke belakang). Indeks dampak penyebaran dan efek keluasan untuk masing-masing sektor produksi di Provinsi Sumatera Utara tahun 1995 dan 2009 ditunjukkan pada Tabel 2 (Lampiran). Kemudian masing-masing sektor produksi tersebut diklasifikasikan ke dalam empat kelompok yang didasarkan dampak penyebaran ditunjukkan pada Tabel 3 (Lampiran).

Indeks dampak penyebaran merupakan nilai yang akan menjadi indikator dalam menentukan sektor-sektor mana yang dampak penyebarannya di atas atau di bawah rata-rata. Sektor yang memiliki indeks dampak penyebaran lebih dari satu menunjukkan dampak penyebaran sektor tersebut di atas rata-rata daya penyebaran secara keseluruhan, yang berarti sektor tersebut memiliki kemampuan yang cukup kuat dalam 
menarik/mendorong sektor hulu/hilir. Sedangkan indeks efek keluasan menunjukkan besarnya keterkaitan (ke depan dan ke belakang) suatu sektor yang disebabkan oleh sejumlah sektor. Apabila indeks keluasan ke depan kurang dari satu berarti suatu sektor memiliki penjualan kepada sejumlah kecil sektor, sedangkan indeks keluasan ke belakang kurang dari satu berarti suatu sektor membeli dari sejumlah kecil sektor.

Berdasarkan Tabel 2 terlihat kinerja subsektor Perkebunan selama periode tahun 1995-2009, apabila ditinjau dari hasil perhitungan indeks kepekaan penyebaran dan efek keluasan (ke depan dan ke belakang) belum menggembirakan, hasilnya kurang dari 1. Hal ini berarti subsektor Perkebunan selain belum memiliki kemampuan yang cukup kuat dalam mendorong sektor hilirnya, juga memiliki pembelian/penjualan kepada sejumlah kecil sektor. Sebenarnya hal itu kurang wajar dari sisi perolehan angka indeks kepekaan penyebaran, karena subsektor ini (juga subsektor lainnya dari sektor Pertanian) merupakan sektor hulu bagi sektor-sektor lainnya di luar Pertanian, seperti sektor yang tergolong dalam industri pengolahan. Apabila dibandingkan dengan subsektor lain yang tergolong dalam sektor Pertanian, subsektor Perkebunan memiliki indeks kepekaan penyebaran tertinggi. Selain itu juga masih lebih besar dari hasil perolehan indeks tersebut dari beberapa subsektor yang tergolong pada sektor industri pengolahan dan jasa-jasa, seperti: Industri keramik, kaca, bahan bukan logam, Listrik, gas dan air minum, Jasa angkutan jalan raya, kereta api, dan perdagangan.

Sebaliknya berdasarkan hasil perhitungan indeks daya penyebaran, subsektor Perkebunan memberikan dampak positip bagi perekonomian Sumatera Utara, hal ini terlihat dari besarnya indeks daya penyebaran yang lebih dari 1. Artinya subsektor Perkebunan memiliki kemampuan yang cukup kuat dalam menarik sektor hulunya. Selain itu yang lebih menggembirakan dari subsektor ini adalah secara rata-rata dari peroleh angka indeks ini dalam kurun waktu 1995-2009 adalah terbesar keenam dari keseluruhan subsektor dan kedua dalam sektor Pertanian. Akan tetapi dalam perkembangannya angka indeks daya penyebaran subsektor ini

QE Journal | Vol.03 - No.03 September 2014 - 186 
mengalami penurunan. Tentunya ada yang menjadi alasan mengapa terjadi keadaan seperti ini. Dari data BPS (2012) dinyatakan Sawit (sebagai salah satu komoditi dari subsekor Perkebunan) tercatat menempati rating tertinggi nilai ekspornya. Selain itu dari sebagian kalangan pengusaha Sawit Indonesia berambisi untuk menempatkan diri sebagai pesaing utama Malaysia sebagai negara pengekspor terbesar CPO.

Selanjutnya bagaimana peran subsektor Perkebunan dibandingkan dengan subsektor lainnya secara keseluruhan yang didasarkan pada dampak penyebaran dapat dilihat pada Tabel 3. Dari Tabel 3 terlihat subsektor Perkebunan memiliki keterkaitan ke belakang (backward linkage) yang lebih dominan, hal ini menyatakan secara lebih tegas bahwa subsektor ini lebih unggul perannya dalam mendorong menarik sektor hulunya.

\section{Pengganda Sektor Perkebunan di Sumatera Utara}

Dari hasil perhitungan koefesien pengganda untuk masing-masing sektor produksi, (pengganda output bruto dan tenaga kerja) ditunjukkan pada Tabel 4 (Lampiran), dan pengganda pendapatan rumahtangga ditunjukkan pada Tabel 5 (Lampiran).

Berdasarkan Tabel 4, terlihat kinerja subsektor Perkebunan selama periode tahun 1995-2009, memberikan dampak positip bagi perekonomian Sumatera Utara. Hal idu didasarkan pada perolehan (secara rata-rata dalam kurun waktu tersebut) koefisien pengganda output bruto nilainya lebih besar dari 3,7. Hal ini berarti akan terjadi perubahan total dampak terhadap output dalam perekonomian Sumatera Utara secara keseluruhan sebesar 3,7 kali akibat adanya peningkatan permintaan output Perkebunan sebesar 1 satuan. Juga didasarkan pada perolehan koefisien pengganda tenaga kerja (meski tidak sebesar pengganda output) memiliki nilai yang lebih besar dari 1,07, dimana dari hasil ini selain menempatkan subsektor Perkebunan di urutan kedua (dari keseluruhan subsektor) dan 
pertama (dalam sektor Pertanian), juga nilainya masih lebih besar dari rata-rata keseluruhan subsektor $(0,98)$.

Sebagai catatan dari temuan ini, walaupun capaian subsektor Perkebunan kurang menggembirakan dibandingkan subsektor lannya secara keseluruhan berdasarkan perolehan nilai koefisien pengganda output, akan tetapi kinerjanya lebih unggul (menempati urutan tertinggi) dibandingkan dengan subsektor lainnya di dalam sektor Pertanian.

Kinerja subsektor Perkebunan menjadi lebih berarti bila ditinjau dari hasil perhitungan koefesien pengganda pendapatan rumahtangga. Selama kurun waktu 1995-2009 terjadi perubahan kontribusi sektor ini, yang semula (tahun 1995) lebih memberikan dampak yang lebih tinggi pada golongan rumahtangga pengusaha pertanian golongan atas (baik di desa maupun di kota). Akan tetapi dalam perkembangannya (sampai dengan tahun 2009), kontribusinya beralih ke rumahtangga golongan rendah (buruh tani dan golongan rendah di desa). Dalam hal ini golongan rumahtangga buruh tani mendapat dampak pengganda pendapatan lebih besar dibandingkan dengan golongan rendah di desa. Dari hasil temuan ini nampak peranan subsektor Perkebunan dalam upaya membantu perekonomian dalam mengatasi masalah kemiskinan dan kesenjangan pendapatan antar golongan rumahtangga. Hasil ini sejalan dengan program pemerintah, khususnya pemerintah daerah Sumatera Utara dan Indonesia pada umumnya, dalam hal mempercepat tercapainya tingkat kesejahteraan masyarakat yang lebih baik, serta mendukung program MDG guna menjadikan masyarakat dunia yang lebih sejahtera.

Didasarkan atas hasil dari Tabel 5, dimana sektor yang memiliki skor total tertinggi ditetapkan sebagai rangking pertama, berikutnya ditetapkan rangking kedua, dan seterusnya sampai pada skor yang terendah ditetapkan rangking paling bawah, teridentifikasi dengan jelas urutan sektor yang menempati posisi 
teratas sampai terbawah apabila dilakukan rangking di Provinsi Sumatera Utara.

Dari Tabel 5 menunjukkan rangking akhir dari masing-masing subsektor, dimana Perkebunan menempati urutan ketiga pada tahun 1995 dan kelima pada tahun 2009. Dari hasil temuan ini terlihat dalam perkembangannya subsektor Perkebunan (dari tahun 19952009) menurun kinerjanya. Namun demikian hal itu masih menggembirakan karena subsektor Perkebunan masih menempati 5 urutan terbesar dari keseluruhan subsektor, dan masih mengungguli dari seluruh subsektor yang ada dalam sektor Pertanian. Dengan demikian subsektor Perkebunan dapat dijadikan sebagai salah satu sektor pemimpin (leading sector).

Keberadaan subsektor Perkebunan yang merupakan salah satu leading sector akan menjadikan tulang punggung struktur perekonomian di Sumatera Utara di masa depan, sehingga hal itu jangan sampai terlepas dari perhatian pemerintah, terutama pemerintah daerah Sumatera Utara, dalam menerapk kebijakan ekonomi yang dibuat. Berdasarkan pola dasar pembangunan Propinsi Sumatera Utara, hal itu sejalan bahwa program selain peningkatan mutu sumberdaya manusia, prioritas pembangunan pada periode mendatang adalah mengembangkan industri yang maju yang didukung oleh pertanian. Oleh karena itu dari hasil studi ini sudah sepantasnya subsektor Perkebunan dapat dijadikan sebagai salah satu dukungannya. Strategi ini merupakan agroindustrialisasi (Agroindustrialization Strategy). Hal ini sejalan dengan hasil penelitian Nugrahadi (2013), Tambunan (1992), Daryanto (1999) dan Benerjee dan Siregar (2002).

\section{SIMPULAN DAN SARAN}

\section{Simpulan}

Berdasarkan hasil dan pembahasan dapat disimpulkan bahwa peran sektor perkebunan di Sumatera Utara ditunjukkan dengan diperoleh hasil yang memiliki Indeks daya penyebaran yang lebih besar dari $(>1)$ artinya sektor pekebunan memiliki kemampuan menarik pertumbuhan sektor hulunya QE Journal | Vol.03 - No.03 September 2014 - 189 
(backward linkages). Selain itu sektor ini memiliki pengganda output bruto lebih dari 3,7 yang artinya bila di injeksi sebesar satu satuan pada sektor ini maka total dampak terhadap output dalam perekonomian Sumatera Utara secara keseluruhan bertambah menjadi 3,7 kali lipat. Dan berdasarkan hasil urutan rangking, perkebunan menempati urutan 5 besar.

\section{Saran}

Saran yang dapat disampakan terkait dengan hasil studi ini adalah sebagai berikut:

1. Pemerintah, terutama pemerintah daerah Sumatera Utara diharapkan untuk bisa memperhatikan subsektor perkebunan melalui dorongan yang lebih besar dalam penanaman modal (domestik dan asing) dan upaya revitalisasi dalam peningkatan nilai tambah.

2. Pemerintah daerah lebih diharapkan meningkatkan upaya sosialisasi kepada pihak invsestor (domestic dan asing) tentang prospek yang menjanjikan dalam menanamkan modalnya di subsektor perkebunan di Sumatera Utara.

3. Diupayakan adanya upaya yang terintegrasi antara pemerintah daerah, pemerintah pusan dan pihak swasta dalam upayanya memberdayakan sumber daya alam dan sumberdaya manusia di sektor perkebunan di Sumatera Utara.

1) Keterbatasan penelitian dalam konstruksi model yang sederhana sehingga bagi penelitian selanjutnya dapat melakukan peneliti serupa dengan memperbaharui data yang terbarukan (update) dan mendisagregasi subsektor Perkebunan ke dalam beberapa komoditas dan pelaku usaha.

\section{DAFTAR PUSTAKA}

Arsyad, L. 1999. Ekonomi Pembangunan. Bagian Penerbitan Sekolah Tinggi Ekonomi YKPN, Yogyakarta.

Bautista, R. 2000. Agriculture-Based Development : A SAM Perspective on Central Vietnam. International Food Policy Research Institute, Washington, DC.

S. Robinson and M. Said. 1999. Alternative Industrial Development Paths for Indonesia : SAM and CGE Analysis. International Food Policy Institute, Washington, DC.

QE Journal |Vol.03 - No.03 September 2014 - 190 
Banerjee, S dan H. Siregar. 2002. Agriculture As The Leading'Sektor. UNSFIR Working Paper 02/02, UNSFIR, Jakarta.

BPS Sumatera Utara. 2012. Sumatera Utara Dalam Angka.

Daryanto, A. 1995. Applications of Input-Output Analysis. Departement of Socio-Economic Sciences Faculty of Agriculture, Bogor.

. 1999. Structural Change and Determinants of Agriculture's Relative Decline. Mimbar Sosek : Journal of Agricultural and Resource SocioEconomics, 12 (3): 75-94.

2000. Growth and Structural Change in The Indonesian Economy : An Input-Output Perspective. Mimbar Sosek : Journal of Agricultural and Resource Socio-Economics, 13 (3) : 2-12.

2001. Social Accounting Matrix Model For Development Policy Analysis. Working Papers No. 03. Departement of Agricultural Socio-Economics, Bogor Agricultural University, Bogor.

Damanik.(2000). Komoditas perkebunan di provinsi Sumatera Utara merupakan komoditas ekspor [Tesis]. Medan: Universtas Sumatera Utara

Ginting, R. 2006. Dampak Pengeluaran Pemerintah Terhadap Pertumbuhan dan Distribusi Pendapatan Di Sumatera Utara : Pendekatan Sistem Neraca Sosial Ekonomi. Disertasi Doktor. Sekolah Pascasarjana, Institut Pertanian Bogor, Bogor.

Nugrahadi. 2007. Keterkaitan (Lingkage) Sektor-Sektor Ekonomi Jawa Barat. Jurnal Ilmu dan Budaya UNAS Jakarta, volume 28, no. 7, Agustus 2007.

Nugrahadi. 2008. Analisis Sumber Pertumbuhan, Keterkaitan dan Distribusi Pendapatan dalam Proses Perubahan Struktual Ekonomi Provinsi Jawa Barat. Disertasi Doktor Program Pascasarjana, Institut Pertanian Bogor,Bogor.

Nugrahadi. 2013. Keragaan Model Kebijakan Pembangunan Ekonomi Sektoral di Sumatera Utara. Quantitave Economics Journal, Volume 02, no. 01, Maret 2013.

QE Journal |Vol.03 - No.03 September 2014 - 191 
Isard, W., I. J. Azis, M. P. Drennan, R. E. Miller, S. Saltzman and E. Thorbecke. 1998. Methods of Interregional and Regional Analysis. Ashgate, Aldershot.

Jhingan, M.L. 2003. Ekonomi Pembangunan dan Perencanaan (Terjemahan). PT. Raja Grafindo Persada, Jakarta.

Pyatt, G. and I. J. Round. 1985. Social Accounting Matrices: A Basic for Planning. The World Bank, Washington, DC.

Robinson, S., A. Cattaneo and M. El-Said. 1998. Estimating a Social Accounting Matrix Using Cross Entropy Methods. TMD Discussion Paper No. 33, International Food Policy Research Institute.

and M. El-Said. 2000. Upadating and Estimating a Social Accounting Matrix Using Cross Entropy Methods. TMD Discussion Paper No. 58, International Food Policy Research Institute.

Round. 2003. Chapter 14: Social Accounting Matices and SAM-Based Multiplier Analysis. Download from Googel Search Engine (14017_Chapter14.pdf).

Sadoulet, E. and A. de Janvry. 1995. Quantitative Development Analysis. The Johns Hopkins University Press, Baltimore.

Siregar, H. 2002. Does The Relative Importance Of Agriculture Increase After The Asian Financial Crisis? UNSFIR Working Paper 02/02, UNSFIR, Jakarta.

Tambunan, M. 1992. Agricultural Development in the Economic Structural Change and the Role of Agro-Industries in Rural Industrialization in Indonesia. In Iwasaki, I., T. Mori and H. Yamaguchi (ed). 1992. Development Stragegies for The 21ST Century. Institute of Developing Economies, Tokyo, Japan

Thorbecke. 2001. The Social Accounting Matrix: Deterministic or Stochastic Concept? Paper prepared for a conference in Honor of Graham Pyatt's retirement, at the Institute of Social Studies, The Hague, Netherlands, November 29 and 30, 2001.

Todaro, M.P. 2000. Economic Development. Seventh Edition. Pearson Education Liminited, New York. 
Lampiran.

Tabel 1. Klasifikasi SAM provinsi Sumatera Utara (51 sektor)

\begin{tabular}{|c|c|c|c|}
\hline \multicolumn{3}{|r|}{ Uraian } & $\begin{array}{l}\text { Kod } \\
\text { e }\end{array}$ \\
\hline \multirow{3}{*}{$\begin{array}{l}\text { Faktor } \\
\text { Produksi }\end{array}$} & \multicolumn{2}{|c|}{ T.K.Penerima Upah dan Gaji } & 1 \\
\hline & \multicolumn{2}{|c|}{ T.K.Bukan Penerima Upah dan Gaji } & 2 \\
\hline & \multicolumn{2}{|l|}{ Kapital } & 3 \\
\hline \multirow{14}{*}{ Institusi } & \multirow{7}{*}{$\begin{array}{l}\text { Rumahtangg } \\
\text { a }\end{array}$} & Buruh Tani & 4 \\
\hline & & Petani Lahan Sempit atau < $1.0 \mathrm{Ha}$ & 5 \\
\hline & & Petani Lahan Luas atau $\geq 1.0 \mathrm{Ha}$ & 6 \\
\hline & & Pendapatan Golongan Rendah di Desa & 7 \\
\hline & & Pendapatan Golongan Atas di Desa & 8 \\
\hline & & Pendapatan Golongan Rendah di Kota & 9 \\
\hline & & Pendapatan Golongan Atas di Kota & 10 \\
\hline & \multicolumn{2}{|l|}{ Perusahaan } & 11 \\
\hline & \multirow{6}{*}{ Pemerintah } & Pengeluaran Belanja Pegawai & 12 \\
\hline & & Pengeluaran Belanja Barang & 13 \\
\hline & & Pengeluaran Belanja Subsidi & 14 \\
\hline & & Pengeluaran Bidang Ekonomi & 15 \\
\hline & & Pengeluaran Bidang Pemb.Daerah & 16 \\
\hline & & Pengeluaran Bidang Pelayanan Umum & 17 \\
\hline \multirow{18}{*}{$\begin{array}{l}\text { Sektor } \\
\text { Produksi }\end{array}$} & \multicolumn{2}{|c|}{ Tanaman bahan makanan } & 18 \\
\hline & \multicolumn{2}{|l|}{ Perkebunan } & 19 \\
\hline & \multicolumn{2}{|l|}{ Peternakan } & 20 \\
\hline & \multicolumn{2}{|l|}{ Kehutanan } & 21 \\
\hline & \multicolumn{2}{|l|}{ Perikanan } & 22 \\
\hline & \multicolumn{2}{|c|}{ Penambangan migas dan penggalian } & 23 \\
\hline & \multicolumn{2}{|c|}{ Ind. makanan, minuman dan tembakau } & 24 \\
\hline & \multicolumn{2}{|c|}{ Ind. pmintlan, pkaian jadi,brg dr kulit } & 25 \\
\hline & \multicolumn{2}{|c|}{ Ind. kayu, brg dari kayu,rotan, bambu } & 26 \\
\hline & \multicolumn{2}{|c|}{ Ind. kertas, brg dr kertas, percetakan } & 27 \\
\hline & \multicolumn{2}{|c|}{ Ind. kimia dsr, ppuk,jamu,brg dr karet } & 28 \\
\hline & \multicolumn{2}{|c|}{ Ind. pengilangan migas } & 29 \\
\hline & \multicolumn{2}{|c|}{ Ind. keramik, kaca, bahan bkn logam } & 30 \\
\hline & \multicolumn{2}{|c|}{ Ind. logam dasar, besi dan baja } & 31 \\
\hline & \multicolumn{2}{|c|}{ Ind. pengangkutan,mesin, dan alatnya } & 32 \\
\hline & \multicolumn{2}{|c|}{ Ind. barang-barang lainnya } & 33 \\
\hline & \multicolumn{2}{|c|}{ Listrik, gas dan air minum } & 34 \\
\hline & \multicolumn{2}{|c|}{ Bangunan/konstruksi } & 35 \\
\hline
\end{tabular}

QE Journal | Vol.03 - No.03 September 2014 - 193 


\begin{tabular}{|l|l|l|}
\hline \multicolumn{2}{|c|}{ Uraian } & $\begin{array}{l}\text { Kod } \\
\text { ed }\end{array}$ \\
\hline \multirow{4}{*}{} & Perdagangan & 36 \\
\cline { 2 - 3 } & Restoran dan hotel & 37 \\
\cline { 2 - 3 } & Jasa angkutan jalan raya, kereta api & 38 \\
\cline { 2 - 3 } & Jasa angkutan laut, danau, sungai & 39 \\
\cline { 2 - 3 } & Jasa angkutan udara & 40 \\
\cline { 2 - 3 } & Jasa penunjang angkutan & 41 \\
\cline { 2 - 3 } & Komunikasi & 42 \\
\cline { 2 - 3 } & Bank dan lembaga keuangan Lain & 43 \\
\cline { 2 - 3 } & Usaha sewa bangunan dan tanah & 44 \\
\cline { 2 - 3 } & Jasa perusahaan & 45 \\
\cline { 2 - 3 } & Pemerintahan & 46 \\
\hline Pajak Tidak Langsung & 47 \\
\hline Anggaran Ruitn Pemda & 48 \\
\hline Anggaran Pembangunan Pemda & 49 \\
\hline Neraca Kapital & 50 \\
\hline Neraca Luar Negeri & 51 \\
\hline
\end{tabular}

QE Journal |Vol.03 - No.03 September 2014 - 194 
Tabel 2. Indeks Dampak Penyebaran dan Efek Keluasan Sektor Produksi Di Provinsi Sumut Tahun 1995 dan 2009

\begin{tabular}{|c|c|c|c|c|c|c|c|c|}
\hline \multirow{2}{*}{ Sektor } & \multicolumn{2}{|c|}{ KP } & \multicolumn{2}{|c|}{ DP } & \multicolumn{2}{|c|}{ KD } & \multicolumn{2}{|c|}{ KB } \\
\hline & 1995 & 2009 & 1995 & 2009 & 1995 & 2009 & 1995 & 2009 \\
\hline Tanaman bahan makanan & 0,9500 & 0,9406 & 1,8230 & 1,7430 & 0,2284 & 0,2432 & 0,2713 & 0,2909 \\
\hline Perkebunan & 0,9732 & 0,9528 & 1,5082 & 1,2461 & 0,2409 & 0,2487 & 0,2750 & 0,2671 \\
\hline Peternakan & 0,9374 & 0,9748 & 1,1027 & 1,0619 & 0,2322 & 0,2565 & 0,2335 & 0,2447 \\
\hline Kehutanan & 0,9299 & 0,9584 & 0,4148 & 0,6380 & 0,2210 & 0,2352 & 0,1988 & 0,2145 \\
\hline Perikanan & 0,9719 & 0,9536 & 0,5952 & 0,7705 & 0,2233 & 0,2418 & 0,2006 & 0,2218 \\
\hline Penambangan migas dan penggalian & 1,0861 & 0,9774 & 1,0791 & 0,7849 & 0,2783 & 0,2396 & 0,2722 & 0,2348 \\
\hline Ind, makanan, minuman dan tembakau & 1,1678 & 1,0596 & 2,8676 & 2,6974 & 0,3262 & 0,3075 & 0,4230 & 0,4505 \\
\hline Ind, pmintlan, pkaian jadi,brg dr kulit & 1,0689 & 0,9813 & 0,9278 & 1,3703 & 0,2538 & 0,3055 & 0,2369 & 0,3231 \\
\hline Ind, kayu, brg dari kayu, rotan, bambu & 1,0316 & 1,0253 & 1,8962 & 1,0037 & 0,3066 & 0,2658 & 0,3556 & 0,2561 \\
\hline Ind, kertas, brg dr kertas, percetakan & 1,0617 & 0,9228 & 0,4994 & 0,7777 & 0,2325 & 0,2460 & 0,2014 & 0,2322 \\
\hline Ind, kimia dsr, ppuk,jamu,brg dr karet & 1,0741 & 1,0129 & 0,9019 & 1,7253 & 0,2439 & 0,3017 & 0,2237 & 0,3424 \\
\hline Ind, pengilangan migas & 0,9599 & 1,1275 & 0,5310 & 0,5684 & 0,2198 & 0,2537 & 0,1965 & 0,2067 \\
\hline Ind, keramik, kaca, bahan bkn lo & 0,8997 & & 0,8069 & & 0,2447 & 0,2441 & 0,2361 & 0,2192 \\
\hline Ind, logam dasar, besi dan baja & 1,0267 & 1,0280 & 1,1496 & 0,8822 & 0,3148 & 0,2775 & 0,3128 & 0,2624 \\
\hline Ind, pengangkutan,mesin, dan a & 0,9920 & 0,9666 & 0,6556 & 1,0066 & 0,2358 & 0,2812 & 0,2149 & 0,2781 \\
\hline Ind, barang-barang lainnya & 1,0825 & & 0,3668 & 0,5063 & 0,2297 & 0,2407 & 0,1962 & 0,2031 \\
\hline Listrik, gas dan air minum & 0,9479 & 0,9449 & 0,7670 & 0,9848 & 0,2312 & 0,2399 & 0,2171 & 0,2362 \\
\hline Bangunan/konstruksi & 0,9668 & 1,0149 & 0,6808 & 1,4695 & 0,2217 & 0,2548 & 0,2036 & 0,2841 \\
\hline Perdagangan & 0,9166 & 0,8967 & 1,6629 & 1,7767 & 0,2330 & 0,2449 & 0,2761 & 0,3155 \\
\hline Restoran dan hotel & 1,1143 & 1,0481 & 1,2338 & 0,8571 & 0,2501 & 0,2550 & 0,2402 & 0,2245 \\
\hline Jasa angkutan jalan raya, kereta api & 0,8967 & 0,9574 & 1,1985 & 0,8343 & 0,2351 & 0,2399 & 0,2434 & 0,2258 \\
\hline Jasa angkutan laut, danau, sungai & 0,9465 & 1,0570 & 0,4720 & 0,4840 & 0,2194 & 0,2416 & 0,1976 & 0,2029 \\
\hline Jasa angkutan udara & 0,9777 & 1,0342 & 0,4626 & 0,4560 & 0,2322 & 0,2390 & 0,2103 & 0,2022 \\
\hline Jasa penunjang angkutan & 0,9791 & 1,0297 & 0,6003 & 0,6102 & 0,2269 & 0,2441 & 0,2076 & 0,2141 \\
\hline Komunikasi & 0,9924 & 1,0142 & 0,5767 & 0,6808 & 0,2291 & 0,2423 & 0,2067 & 0,2152 \\
\hline Bank dan lembaga keuangan Lain & 1,0826 & 0,9848 & 0,6794 & 0,7983 & 0,2498 & 0,2421 & 0,2035 & 0,2235 \\
\hline Usaha sewa bangunan dan tanah & 0,9696 & 0,9822 & 1,1083 & 0,8199 & 0,2352 & 0,2410 & 0,2340 & 0,2221 \\
\hline Jasa perusahaan & 0,9747 & 1,0672 & 0,5864 & 0,5409 & 0,2249 & 0,2415 & 0,2015 & 0,2053 \\
\hline Pemerintahan & 1,0220 & 1,0202 & 1,8456 & 1,1447 & 0,2566 & 0,2548 & 0,2994 & 0,2535 \\
\hline
\end{tabular}

Sumber : SAM Propinsi Sumut Tahun 1995 dan 2009 (Diolah)

Keterangan :

$\mathrm{KP}=$ kepekaan penyebaran

$\mathrm{DP}=$ daya penyebaran

$\mathrm{KD}=$ efek keluasan ke depan

KB =efek keluasan ke belakang

QE Journal |Vol.03 - No.03 September 2014 - 195 
Tabel 3. Klasifikasi Indeks Dampak Penyebaran Sektor Produksi Di Provinsi Sumut Tahun 1995 dan 2009 Menurut Empat Kelompok

\begin{tabular}{|c|c|c|c|c|c|}
\hline & \multicolumn{4}{|c|}{ Kepekaan Penyebaran } \\
\hline & & \multicolumn{2}{|c|}{$>1$} & \multicolumn{2}{|c|}{$<1$} \\
\hline & & 1995 & 2009 & \multirow{2}{*}{\begin{tabular}{|c|}
1995 \\
Tanaman perkebunan
\end{tabular}} & \multirow{2}{*}{$\begin{array}{c}2009 \\
\text { Tanaman perkebunan }\end{array}$} \\
\hline \multirow{18}{*}{ 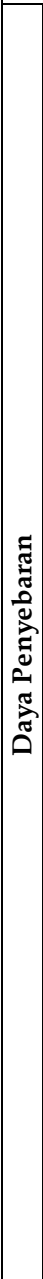 } & \multirow{6}{*}{$>1$} & \begin{tabular}{|lr} 
Ind, & makanan, \\
minuman & dan \\
tembakau & \\
\end{tabular} & \begin{tabular}{|lr} 
Ind, & makanan, \\
minuman & dan \\
tembakau & \\
\end{tabular} & & \\
\hline & & $\begin{array}{l}\text { Ind, kayu, brg dari } \\
\text { kayu,rotan, bambu }\end{array}$ & $\begin{array}{l}\text { Ind, kayu, brg dari } \\
\text { kayu,rotan, bambu }\end{array}$ & $\begin{array}{l}\text { Tanaman } \\
\text { makanan }\end{array}$ & $\begin{array}{l}\text { Tanaman } \\
\text { makanan }\end{array}$ \\
\hline & & $\begin{array}{l}\text { Ind, logam dasar, besi } \\
\text { dan baja }\end{array}$ & $\begin{array}{lrr}\text { Ind, kimia } & \text { dsr, } \\
\text { ppuk,jamu,brg dr karet }\end{array}$ & Peternakan & Peternakan \\
\hline & & $\begin{array}{l}\text { Penambangan migas } \\
\text { dan penggalian }\end{array}$ & Bangunan/konstruksi & Perdagangan & $\begin{array}{l}\text { Ind, pmintlan, pkaian } \\
\text { jadi,brg dr kulit }\end{array}$ \\
\hline & & Restoran dan hotel & Pemerintahan & $\begin{array}{l}\text { Jasa angkutan jalan } \\
\text { raya, kereta api }\end{array}$ & $\begin{array}{l}\text { Ind, } \\
\text { pengangkutan,mesin, } \\
\text { dan alatnya }\end{array}$ \\
\hline & & Pemerintahan & & $\begin{array}{l}\text { Usaha sewa bangunan } \\
\text { dan tanah }\end{array}$ & Perdagangan \\
\hline & \multirow{12}{*}{$<1$} & $\begin{array}{ll}\begin{array}{l}\text { Ind, kimia } \\
\text { ppuk,jamu,brg dsr, } \\
\text { karet }\end{array} & \text { dr } \\
\end{array}$ & Ind, pengilangan migas & Kehutanan & Kehutanan \\
\hline & & $\begin{array}{l}\text { Ind, pmintlan, pkaian } \\
\text { jadi,brg dr kulit }\end{array}$ & \begin{tabular}{ll|} 
Ind, barang-barang \\
lainnya
\end{tabular} & Perikanan & Perikanan \\
\hline & & $\begin{array}{l}\text { Ind, kertas, brg dr } \\
\text { kertas, percetakan }\end{array}$ & $\begin{array}{l}\text { Ind, logam dasar, besi } \\
\text { dan baja }\end{array}$ & $\begin{array}{l}\text { Ind, keramik, kaca, } \\
\text { bahan bkn logam }\end{array}$ & $\begin{array}{l}\text { Ind, kertas, brg } \mathrm{dr} \\
\text { kertas, percetakan }\end{array}$ \\
\hline & & $\begin{array}{l}\text { Ind, barang-barang } \\
\text { lainnya }\end{array}$ & $\begin{array}{l}\text { Ind, keramik, kaca, } \\
\text { bahan bkn logam }\end{array}$ & $\begin{array}{l}\text { Ind, } \\
\text { pengangkutan,mesin, } \\
\text { dan alatnya } \\
\end{array}$ & $\begin{array}{l}\text { Bank dan lembaga } \\
\text { keuangan Lain }\end{array}$ \\
\hline & & $\begin{array}{l}\text { Bank dan lembaga } \\
\text { keuangan Lain }\end{array}$ & Restoran dan hotel & $\begin{array}{ll}\begin{array}{l}\text { Ind, } \\
\text { migas }\end{array} & \text { pengilangan } \\
\end{array}$ & $\begin{array}{l}\text { Usaha sewa bangunan } \\
\text { dan tanah }\end{array}$ \\
\hline & & & Jasa angkutan udara & \begin{tabular}{|ll} 
Jasa & penunjang \\
angkutan
\end{tabular} & $\begin{array}{l}\text { Penambangan migas } \\
\text { dan penggalian }\end{array}$ \\
\hline & & & $\begin{array}{|ll|}\text { Jasa penunjang } \\
\text { angkutan }\end{array}$ & Jasa angkutan udara & $\begin{array}{l}\text { Listrik, gas dan air } \\
\text { minum }\end{array}$ \\
\hline & & & Komunikasi & Jasa perusahaan & \\
\hline & & & Jasa perusahaan & Bangunan/konstruksi & \\
\hline & & & $\begin{array}{l}\text { Jasa angkutan laut, } \\
\text { danau, sungai }\end{array}$ & $\begin{array}{l}\text { Listrik, gas dan air } \\
\text { minum }\end{array}$ & \\
\hline & & & & $\begin{array}{l}\text { Jasa angkutan laut, } \\
\text { danau, sungai }\end{array}$ & \\
\hline & & & & Komunikasi & \\
\hline
\end{tabular}

Sumber : SAM Propinsi Sumut Tahun 1995 dan 2009 (Diolah) 
Tabel 4. Koefisien Pengganda Output Bruto dan Tenaga Kerja Menurut Sektoral di Propinsi Sumatera Utara Tahun 1995 dan 2009

\begin{tabular}{|l|c|c|c|c|}
\hline \multirow{2}{*}{ Sektor } & \multicolumn{2}{c|}{ Output Bruto } & \multicolumn{2}{c|}{ Tenaga Kerja } \\
\cline { 2 - 5 } & $\mathbf{1 9 9 5}$ & $\mathbf{2 0 0 9}$ & $\mathbf{1 9 9 5}$ & $\mathbf{2 0 0 9}$ \\
\hline Tanaman bahan makanan & 3,3647 & 3,9701 & 1,0884 & 1,0199 \\
Perkebunan & $\mathbf{3 , 4 4 6 8}$ & $\mathbf{4 , 0 2 1 4}$ & $\mathbf{1 , 0 3 9 4}$ & $\mathbf{1 , 1 0 9 9}$ \\
Peternakan & 3,3200 & $\mathbf{4 , 1 1 4 5}$ & 1,0688 & 0,9404 \\
Kehutanan & 3,2934 & 4,0451 & 0,9374 & 0,9701 \\
Perikanan & 3,4422 & 4,0251 & 1,1009 & 1,0071 \\
Penambangan migas dan penggalian & 3,8467 & 4,1254 & 0,9696 & 1,0236 \\
Industri Makanan, Minuman \& Tembakau & 4,1362 & 4,4721 & 1,0272 & 0,9806 \\
Ind. pmintlan, pkaian jadi, brg dari kulit & 3,7858 & 4,1416 & 1,0573 & 0,8909 \\
Ind. kayu, brg dari kayu, rotan, bambu & 3,6536 & 4,3277 & 0,9020 & 0,9810 \\
Ind. kertas, brg dr kertas, percetakan & 3,7604 & 3,8948 & 0,9490 & 0,7895 \\
Ind. kimia dsr, ppuk,jamu,brg dr karet & 3,8042 & 4,2753 & 0,9755 & 0,9230 \\
Ind. pengilangan migas & 3,3996 & 4,7591 & 1,0190 & 1,0224 \\
Ind. keramik, kaca, bahan bkn logam & 3,1864 & 4,2758 & 0,7893 & 0,9441 \\
Ind. logam dasar, besi dan baja & 3,1559 & 4,3389 & 0,8605 & 0,9383 \\
Ind. pengangkutan, mesin dan alatnya & 3,6365 & 4,0797 & 0,9394 & 0,9051 \\
Ind. barang-barang lainnya & 3,5134 & 4,4481 & 0,9559 & 0,9574 \\
Listrik, gas dan air minum & 3,8339 & 3,9884 & 0,9007 & 0,9518 \\
Bangunan/konstruksi & 3,3572 & 4,2836 & 0,9949 & 1,0179 \\
Perdagangan & 3,4241 & 3,7848 & 1,0287 & 1,0060 \\
Restoran dan hotel & 3,2463 & 4,4239 & 1,0129 & 0,9872 \\
Jasa angkutan jalan raya, kereta api & 3,9467 & 4,0410 & 0,9254 & 1,0195 \\
Jasa angkutan laut, danau, sungai & 3,3524 & 4,4612 & 0,9110 & 1,0046 \\
Jasa angkutan udara & 3,4626 & 4,3650 & 0,8443 & 0,9623 \\
Jasa penunjang angkutan & 3,4679 & 4,3463 & 1,0113 & 1,0308 \\
Komunikasi & 3,5148 & 4,2806 & 1,0240 & 1,0525 \\
Bank dan lembaga keuangan Lain & 3,8345 & 4,1566 & 0,9136 & 1,0527 \\
Usaha sewa bangunan dan tanah & 3,4342 & 4,1457 & 0,9543 & 1,0077 \\
Jasa perusahaan & 3,4523 & 4,5046 & 1,0186 & 1,0475 \\
Jasa Pemerintahan & 3,6197 & 4,3059 & 1,2562 & 1,3085 \\
\hline
\end{tabular}

Sumber : SAM Propinsi Sumatera Utara Tahun 1995 dan 2009 (Diolah) 
Tabel 5. Rangking Sektoral di Propinsi Sumater Utara Tahun 1995 dan 2009

\begin{tabular}{|c|c|c|c|c|c|c|c|c|c|c|c|c|}
\hline \multirow[b]{4}{*}{ Sektor } & \multicolumn{12}{|c|}{ Rangking } \\
\hline & \multirow{2}{*}{\multicolumn{2}{|c|}{$\begin{array}{c}\text { Output } \\
\text { Bruto }\end{array}$}} & \multicolumn{4}{|c|}{ Keterkaitan } & \multirow{2}{*}{\multicolumn{2}{|c|}{$\begin{array}{c}\text { Tenaga } \\
\text { kerja }\end{array}$}} & \multirow{2}{*}{\multicolumn{2}{|c|}{$\begin{array}{c}\text { Pendapatan } \\
\text { RT }\end{array}$}} & \multirow{2}{*}{\multicolumn{2}{|c|}{ Total }} \\
\hline & & & \multicolumn{2}{|c|}{$\begin{array}{c}\text { Ke } \\
\text { Belakang } \\
\end{array}$} & \multicolumn{2}{|c|}{$\begin{array}{c}\text { Ke } \\
\text { Depan }\end{array}$} & & & & & & \\
\hline & $\begin{array}{c}199 \\
5\end{array}$ & $\begin{array}{c}200 \\
9\end{array}$ & $\begin{array}{c}199 \\
5\end{array}$ & $\begin{array}{c}200 \\
9\end{array}$ & $\begin{array}{c}199 \\
5\end{array}$ & $\begin{array}{c}200 \\
9\end{array}$ & $\begin{array}{c}199 \\
5\end{array}$ & $\begin{array}{c}200 \\
9\end{array}$ & 1995 & 2009 & $\begin{array}{c}199 \\
5\end{array}$ & $\begin{array}{c}200 \\
9\end{array}$ \\
\hline Tanaman bahan makanan & 22 & 27 & 22 & 27 & 3 & 3 & 3 & 9 & 2 & 6 & 4 & 14 \\
\hline Perkebunan & 17 & 25 & 18 & 25 & 6 & 7 & 6 & 2 & 4 & 2 & 3 & 5 \\
\hline Peternakan & 25 & 20 & 21 & 20 & 10 & 9 & 4 & 24 & 6 & 22 & 12 & 26 \\
\hline Kehutanan & 26 & 22 & 19 & 22 & 28 & 23 & 21 & 19 & 11 & 14 & 25 & 28 \\
\hline Perikanan & 18 & 24 & 11 & 24 & 20 & 20 & 2 & 13 & 10 & 13 & 7 & 21 \\
\hline $\begin{array}{l}\text { Penambangan migas dan } \\
\text { penggalian }\end{array}$ & 3 & 19 & 8 & 19 & 12 & 18 & 16 & 7 & 17 & 5 & 5 & 3 \\
\hline Industri Makanan, Minuman \& & J & 19 & 0 & 19 & 12 & 10 & 10 & $\gamma$ & 17 & 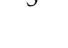 & 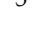 & 3 \\
\hline Tembakau & 1 & 3 & 7 & 3 & 1 & 1 & 8 & 18 & 8 & 17 & 1 & 6 \\
\hline $\begin{array}{l}\text { Ind. pmintlan, pkaian jadi,brg } \\
\text { dari kulit }\end{array}$ & 7 & 18 & 6 & 18 & 13 & 6 & 5 & 28 & 9 & 28 & 2 & 22 \\
\hline $\begin{array}{l}\text { Ind. kayu, brg dari kayu,rotan, } \\
\text { bambu }\end{array}$ & 9 & 10 & 24 & 10 & 4 & 11 & 25 & 17 & 27 & 20 & 22 & 19 \\
\hline $\begin{array}{l}\text { Ind. kertas, brg dr kertas, } \\
\text { percetakan }\end{array}$ & 8 & 28 & 4 & 28 & 25 & 19 & 19 & 29 & 20 & 29 & 17 & 29 \\
\hline $\begin{array}{l}\text { Ind. kimia dsr, ppuk,jamu,brg } \\
\text { dr karet }\end{array}$ & 6 & 15 & 5 & 15 & 14 & 4 & 15 & 26 & 16 & 26 & 6 & 15 \\
\hline Ind. pengilangan migas & 21 & 1 & 14 & 1 & 24 & 25 & 10 & 8 & 3 & 10 & 13 & 8 \\
\hline $\begin{array}{l}\text { Ind. keramik, kaca, bahan bkn } \\
\text { logam }\end{array}$ & 28 & 14 & 27 & 14 & 15 & 21 & 29 & 23 & 29 & 21 & 29 & 20 \\
\hline $\begin{array}{l}\text { Ind. logam dasar, besi dan baja } \\
\text { Ind. pengangkutan,mesin, dan }\end{array}$ & 29 & 9 & 25 & 9 & 11 & 13 & 27 & 25 & 28 & 25 & 28 & 24 \\
\hline alatnya & 10 & 21 & 12 & 21 & 19 & 10 & 20 & 27 & 23 & 27 & 20 & 23 \\
\hline Ind. barang-barang lainnya & 13 & 5 & 2 & 5 & 29 & 27 & 17 & 21 & 19 & 23 & 19 & 27 \\
\hline Listrik, gas dan air minum & 5 & 26 & 20 & 26 & 16 & 12 & 26 & 22 & 22 & 24 & 23 & 25 \\
\hline Bangunan/konstruksi & 23 & 12 & 13 & 12 & 17 & 5 & 14 & 11 & 21 & 18 & 21 & 17 \\
\hline Perdagangan & 20 & 29 & 23 & 29 & 5 & 2 & 7 & 14 & 7 & 9 & 9 & 11 \\
\hline Restoran dan hotel & 27 & 6 & 1 & 6 & 7 & 14 & 12 & 16 & 15 & 16 & 8 & 16 \\
\hline $\begin{array}{l}\text { Jasa angkutan jalan raya, kereta } \\
\text { api }\end{array}$ & 2 & 23 & 26 & 23 & 8 & 15 & 22 & 10 & 18 & 12 & 16 & 12 \\
\hline $\begin{array}{l}\text { Jasa angkutan laut, danau, } \\
\text { sungai }\end{array}$ & 24 & 4 & 16 & 4 & 26 & 28 & 24 & 15 & 25 & 15 & 27 & 13 \\
\hline Jasa angkutan udara & 15 & 7 & 15 & 7 & 27 & 29 & 28 & 20 & 24 & 19 & 26 & 18 \\
\hline Jasa penunjang angkutan & 14 & 8 & 10 & 8 & 21 & 24 & 13 & 6 & 5 & 7 & 10 & 9 \\
\hline Komunikasi & 12 & 13 & 9 & 13 & 23 & 22 & 9 & 4 & 12 & 4 & 11 & 10 \\
\hline $\begin{array}{l}\text { Bank dan lembaga keuangan } \\
\text { Lain }\end{array}$ & 4 & 16 & 3 & 16 & 18 & 17 & 23 & 3 & 26 & 3 & 15 & 4 \\
\hline $\begin{array}{l}\text { Usaha sewa bangunan dan } \\
\text { tanah }\end{array}$ & 19 & 17 & 17 & 17 & 9 & 16 & 18 & 12 & 14 & 11 & 18 & 7 \\
\hline Jasa perusahaan & 16 & 2 & 28 & 2 & 22 & 26 & 11 & 5 & 13 & 8 & 24 & 2 \\
\hline Jasa Pemerintahan & 11 & 11 & 29 & 11 & 2 & 8 & 1 & 1 & 1 & 1 & 14 & 1 \\
\hline
\end{tabular}

